\title{
Study on the Development of the Banking Industry in Ghana with Evidence to Innovation Technology
}

\author{
Bekoe Bernard Boamah $^{1} \quad$ Naffixa Afua Dadzie ${ }^{2} \quad \mathrm{Yu} \mathrm{Bo}^{3}$ \\ 1.Business School, Hohai University, Nanjing, 211100, P.R.China \\ 2.Department of Management, NUIST, Nanjing, 211100, P.R. China
}

\begin{abstract}
Innovation technology is currently recognized as one of the key factors in the firms' competitive advantage as well as a critical element in improving the economic and financial results of firms. Increased economic and financial performance have been observed among firms capable of using innovation to improve their processes or differentiate their products and services in relation to their competitors. This study employs both quantitative and qualitative methods in analyzing the Administrated questionnaires. Primary data were collected using the random sampling procedure among Ghana banking workers and customers. Google Forms was used in answering the questionnaires, which automatically generated simple graphs. The data was also interpreted in table forms for easy analysis and reading. The research used SPSS (Statistical Package for Social Sciences) to analyze the correlation statistics that were adopted from the responses of the questionnaire. The Spearman and Kendall's tau-b was also adopted in this study. The overall study of the research is to identify the influence innovation technology has brought on the banking industry. Emerged from the study were: the ease use of innovation technology products by customers and employees of the bank. The respondents from the survey shows positive significance impact of innovation technology in their daily use of bank services such as Internet Banking, ATM, Mobile Banking, due to this, the banking industry keeps expanding and introducing new varieties of innovation to be able to gain stands in competition with other banks and financial institutions. With this outcome, banks should focus on more innovation technology products to enhance the lives of their workers and customers, which significantly also increases productivity and profit.
\end{abstract}

Keywords: Banking Industry, Innovation, Technology, Banking, Ghana, customer satisfaction.

DOI: $10.7176 /$ RJFA/10-6-11

Publication date:March $31^{\text {st }} 2019$

\section{Introduction}

The increase in customer service delivery, market share, quality and efficient cost of production and developing new products have been necessitated by the kind and quality of innovative technology the organization employs. E-banking concept becomes popular when banking activities and information technology are merged. The banking transaction becomes easy after the introduction of electronic equipment such as computers, printers Automated Teller Machine etc. in banking sector. The banks are able to automate the accounting process and back office functions like calculation of interests, balancing daily transactions and general ledger calculations. The introduction of innovative technology also allows customers to do self-service transaction (e-service). The automation of front office function improves the customer service with reduction in processing time, hence improving the overall performance of Ghana banks. Commercial/retail banks are typically concerned with managing withdrawals and receiving deposits as well as supplying short-term loans to individuals and small businesses. Consumers primarily use these banks for basic checking and savings accounts, and home mortgage. Investment banks on the other hand concentrate on providing corporate clients with services such as funding and assisting with merger and acquisition (M\&A) activities. In most countries, banks are regulated by the national government or central bank. Technological innovations are intensely shifting the way things are done, development in Electronic trade is now supposed to give rise to the promise of a new commercial insurgence by offering an economical and direct way to transact business. This uprising has set in nod a revolution in the banking sector for the provision of a payment system that is compatible with the demands of the electronic marketplace (Balachandher et al 2001). Credited with helping fuel strong growth in many economies, it seems without any apparent doubt that, technological innovation affects not just banks and banking and financial services, but also the course of an economy and its capacity for continued growth and development, (Coombs et al, 1987). According to Alu (2002), Technological innovations not only touches financial institutions by easing enquiry, saving time, and improving service delivery, but has also in recent times, due investments in it by banks served to streamline operations, improve competitiveness, and increase the variety and quality of services provided. Yasuharu (2003), posits that not only has innovations in the banking industry brought it development, but has also brought a revolution in the functioning of the banks and the financial institutions as well. Numerous banks are making what appear like massive investment in technology and innovation to keep and upgrade their infrastructure, in order not only to provide new electronic information-based services, but also to manage their risk positions and pricing. These developments may eventually change the competitive landscape in the financial 
services and Banking as a whole. Innovation is a double edged-sword: the right kind of innovation and favorable conditions that may spur banks to invest in new technologies would help the financial system fulfill its functions and, as a consequence, deliver growth; but too much of innovation or innovation which is not properly used can have serious consequences on the overall economy (Stiglitz 2010 ) (Beck et al. 2012).

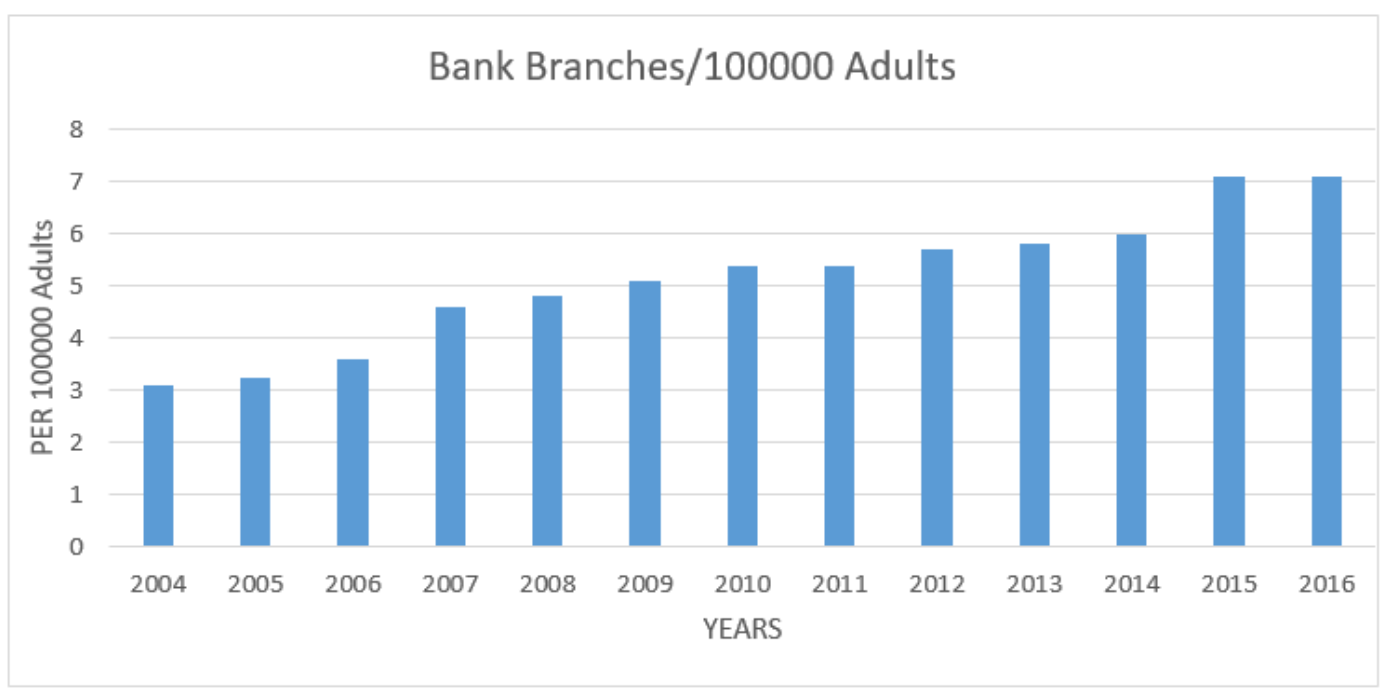

Figure 1. Banks Branches

Source: World Bank Data (worldbank.org)

Bank accessibility has surged over the years in company to accompany the recent galloping Ghanaian population in the past decade. Figure--- above clearly indicates that, an average of 3 banks were accessible to every 100000 Ghanaian adults in 2004. Even though Ghana's population has more than doubled since 2004, the number of bank branches (a perfect proxy for bank accessibility) has more than doubled. This clearly indicates the rapid and positive evolution of the banking sector in Ghana. The features of innovation in the banking sector are quite different from the characteristics usually encountered in other sectors. Banks are not the only developer of financial innovation. The banking sector is one industry that has the stigma or tendency of outliving it systems and structures of operations; However, a global trend of deregulation and the mode of operations within the banking industry has unlocked up several innovative ideas thereby unfolding technological developments like the introduction of internet banking and self-service (ATMs). The banking industry is palpably trying its utmost best to shed its boring and cumbersome image. Banks are also significant users of financial technologies that employ economic and statistical models to create and value new securities, estimate return distributions, and make portfolio decisions based on financial data. Examples include financial engineering used to create new financial derivatives, credit risk and market risk models employed to improve portfolio management. Arguably, the most revolutionary electronic innovation in this country and the world over has been the ATM. In Ghana, banks with ATM offerings have them networked and this has increased their utility to customers. The Trust Bank Ghana, in 1995 installed the first ATM. Not long after, most of the major banks began their ATM networks at competitive positions. Figure 2 below shows the number of Automated Teller Machines and Bank Branches available per each 100000 adults since 2005. Apart from the sharp decline in 2016 from the previous year (which might have been caused by the sudden surge in their adult population), the ratio of the ATM accessibility has seen a steady rise signaling a positive integration of technology into the banking industry of Ghana from the recent past decade. 


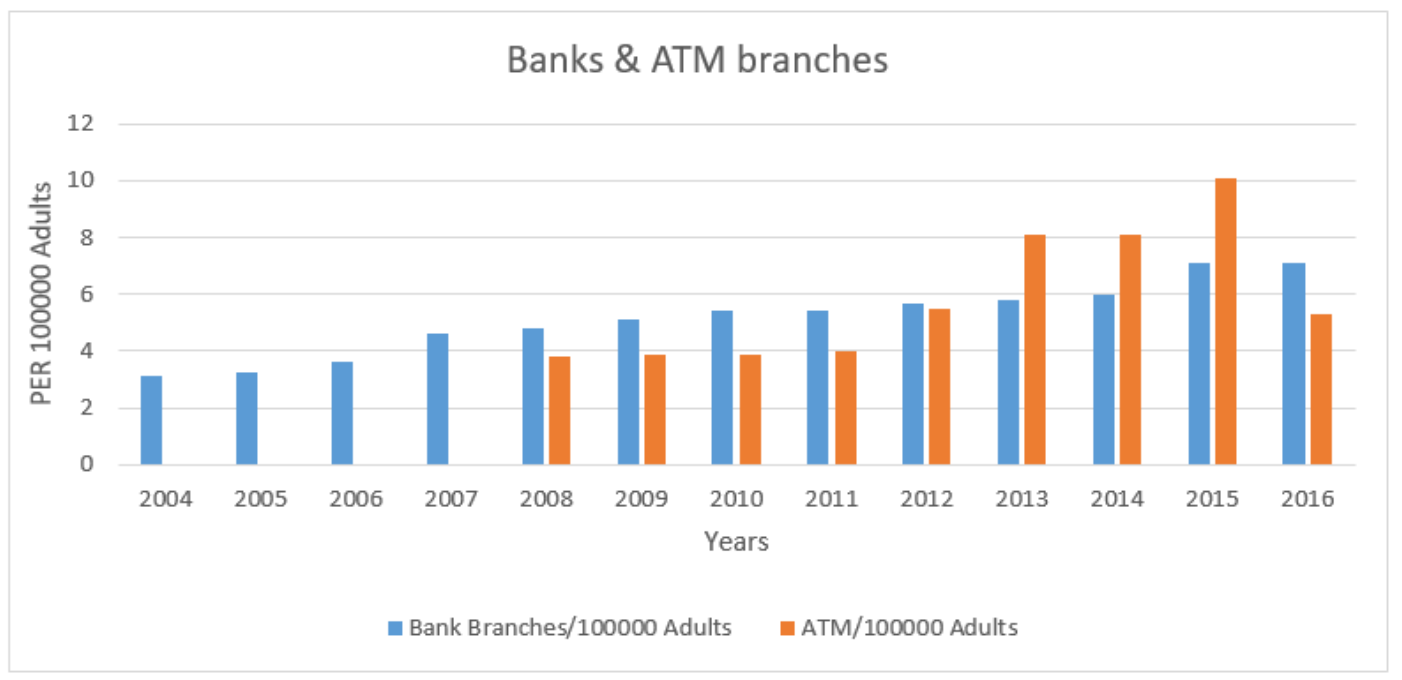

Figure 2: Banks and ATM Branches

Source: World Bank Data (worldbank.org)

Banking in Ghana has experienced many modifications in service delivery with the aim of improving the quality of service being provided to the customers. Banks were delivering services to their customers manually that is walking to the banking hall queue up and wait for your turn to be served. The other problem faced by many Ghanaians is that companies and individuals mostly do not accept cheques as payment method. This is because of the time and the inconveniences involved in accepting and depositing cheques in the designated accounts. . As of December 1984, there were twelve (12) banks in Ghana. From that period to May 2012, several other banks been incorporated into the Ghanaian banking sector. A large number of these new banks are now owned and managed by Africans, and the sector boasts a number of highly skilled and experienced bankers. Bank branches in Ghana increased by $11.3 \%$ from 309 to 344 between 2002 and 2004. The total banking system assets at the end of October 2006 were $\phi 48,353.0$ billion, representing an annual growth of $35.5 \%$, as against $16.6 \%$ as of the end of October 2005. There has been a broad opening in innovation technology in the world for most banks and they are presently taking advantage of these developments to deliver better enhanced customer and more efficient and effective services that will increase productivity (Akinuli, 1999).Yet, some banking sector like the rural banks in Ghana, which is a key strategic sector in the Ghanaian banking industry aimed at accelerating rural and agricultural development, appears to have a blurred picture in the adoption of IT in its operations in the country. The very few study that focused on rural and community banks accessed the impact of IT only on their service delivery, with lacking conclusions of its impact on profitability, loan recovery, deposit mobilization and failing to also address the knowledge and effectiveness of Innovation Technology in the Banking Industry and. Therefore, this constitutes a research gap and this thesis proposes to fill this gap. This study therefore sought to examine the development of innovation technology on the performance of the Banking Industries in Ghana using major Banks, which has advance in technology usage in the Cities of Ghana as a case study.

This study is organized into five main chapters. Chapter one covers the introduction which includes the background to the study, statement of the problem, purpose of the study, objectives of the study, research questions, significance of the study, scope and limitations of the study, definition of terms and structure of the study. Chapter two contains the literature review. Chapter three covers the methodology. Chapter four covers the data analysis, discussion and presentation of research results, while chapter five contains the summary, conclusion and recommendations of the study.

\section{Literature Review}

\subsection{Innovation and Technology adoption}

Innovation is described as any good, service or idea that is perceived by someone as new (Kotler, 2003). According to Rogers (1995), innovation takes time to spread through the social system and innovation diffusion process is a new idea becoming widespread from its source of invention or creation to its ultimate users or adopters. Baker (2002) posits that the primary drivers of innovation include, financial pressures to decrease costs and increase efficiency, increased competition, shorter product life cycles, value migration, stricter regulations, industry and community needs for sustainable development, increased demand for accountability, community and social expectations and pressures, demographic, social and market changes, rising customer expectations regarding service and quality, greater availability of potentially useful new technologies coupled with the need to 
keep up or exceed the competition in applying these new technologies, and the changing economy.

Similar considerations can be found in (Frame and White 2004) and in (Tufano 2003), who define innovation employing a few key concepts, such as the completion of incomplete markets, the overcoming of agency problems and information asymmetries, the reduction of transaction, research, or marketing costs, the response to taxation and regulation changes and the link to globalization, risks and technological shocks. An innovation is defined as a new idea or a new or substantially improved good or service that has been commercialized or any substantially new improved process for the commercial production of goods and services (Roger 1995). Fisher (1998) notes technology when applied in today's banking environment falls into three specific categories: customer independent (a technology that involves a customer conducting and completing a transaction with a bank entirely independent of any human contact with the institution e.g. ATMs, phone banking and Internet banking); customer assisted (a bank employee will use customer-assisted technology as a resource to complete a transaction e.g. call Centre's customer service officers will use a Customer Relationship Management (CRM) System to understand a customer's profile and provide instant responses to customers' queries on the banking transactions and up to date billings (Gutek \& welsh 1999); and customer transparent Customer technology which represents the real core of the bank operations and customers never see it but expect it. From the point of view of the impact on the industry, innovation may be radical, revolutionary or incremental (Gardner 2009). Radical innovation changed the whole industry, but it has occurred from time to time in banking. Revolutionary innovation tends to be less risky than breakthroughs but also less profitable. Incremental innovation consists of a minor improvement of something already existing, has relatively lower risk and positive payback. It is far more common than radical and revolutionary one. We exclude innovation promoted by changes in regulation or legal provisions, since usually it affects the banking system as a whole. This choice skims the dataset from redundant observations. Finally, in labor intensive industry, such as the banking sector, the innovation process is dominated by "providers" (Pavitt, 1984). A major driver in financial innovation is the development of financial technology broadly defined (Frame and White, 2012; Wall, 2014). Advances in technology have been critical not only in retail banking (e.g. automatic teller machine), but also to obtain, store and process data required to estimate statistical models (e.g. valuation and risk management). Therefore, we include technological innovation as reported by banks in our investigation.

\subsection{E-Banking}

E-banking innovations are technological innovations since they allow customers to access financial services in a convenient and quick manner, without having to visit the premises of a financial facility. Such innovations also help to improve the efficiency of financial intermediation within the financial services industry (Laukkanen 2007). The extent to which innovation attributes influence the adoption of innovation has been copiously documented in the literature. Lean et al. (2009) (Tan and Thoen 2001) and (Teo and Pok 2003) have shown that perceived innovation Knowledge Persuasion Decision Implementation Confirmation Reject Adoption of financial innovation in the Ghanaian banking industry attributes significantly influence decisions. Vilattes (1997) defines E-banking as a distance banking that not only handles the flow of information between customers' "living spaces" (e.g. homes, offices, etc.) and the physical facilities of the bank, but also deals with solicitation, sales, distribution and access to services, all without requiring the customer and the financial institution representative to be in the same physical place at the same time. According to Mols (1998), electronic banking is the automated delivery of new and traditional banking products and services directly to customers through electronic medium. This system allows customers to access their accounts, transact business, make enquiries and have prompt responses from banks. The use of information technology in banking operations is called electronic banking. Josiah and Nancy, (2012) observed that there are positive impacts of e-banking on bank turnover and profitability and to a lesser extent on employment, most notably when ecommerce is part of larger business strategies of bank. The use of e-banking can contribute to improved bank performance, in terms of increased market share, expanded product range, customized products and better response to client demand. Only banks that use their technology resources effectively have the opportunity to secure real competitive advantage in this fast-changing industry through real product or service differentiation. The fast spread of Internet banking may result in the benefits of this technology going primarily to consumers as banks incur the costs of providing these sites to maintain market shares. Due to the ATMs, telephone banking and internet banking services, POS machines, Electronic Fund Transfer (EFT) processes, credit cards, kiosk banks, WAP banking, Palm banking and other new product and distribution channels that have been alternatively developed in the branch banking (Bayrakdaroglu 2012). The cost-efficiency in the internet process, carry off, product variety, increasing the customer focus, decreasing the expenditures of the branch, staff and rents, providing services without depending on the geographic region and time (Pala and Kartal 2010), the roles of the electronic banking that has been widely disseminated around the world for the banks and consumers (Yildiz and Karadirek 2014) has been increasing to change the habits of the consumers (Sanders, 2000). Internet banking has some risks apart from the facilities. This risk that could be defined as security risk is to access to the private information and accounts of 
the account holders by people in bad faith (Ilci Eti and Aslan 2008). Such kind of actions could be in different ways such as inattention of account holder, sharing private information with others or ill-affected banking staff so that they could use the information achieved and it could occur because of hackers so they could access to the computers of the account holders by using the spy programs In order to remove the risks about the security issue of the Internet banking, the consumers who use the banks and internet banking take various precautions. From the review literature, it is quite apparent that the contribution of internet and technology innovation to the banking sector is limitless. This study studies the impact of technology innovation on the banking services and customer satisfaction in the Ghanaian banking sector.

\section{Methodology}

\subsection{Introduction}

This study employs both quantitative and qualitative methods in analyzing the Administrated questionnaires. Primary data were collected using the random sampling procedure among Ghana banking customers. Google Forms was used in answering the questionnaires, which automatically generated simple graphs. The data was also interpreted in table forms for easy analysis and reading. Conclusion was drawn after analyzing the data. Data (responses from Questionnaires) collected was analyzed using Correlation Statistics that were adopted in Statistical Package for Social Science (SPSS). The Spearman and Kendall's tau-b correlation test was adopted. The correlation coefficient expresses the strength of the relationship on a scale, ranging from -1 to +1 . A positive value close to +1 indicates a strong positive relationship, in which an increase in one variable implies an increase in the value of the second variables (Ilo 2014); while a strong negative relationship close to-1 indicates that an increase in one variable leads to a decrease in the other. The extent of correlation is considered at 0.01 levels of significance. The null hypotheses were tested at $5 \%$ level of significance in all cases. The heuristic evaluation method adopted, ensures validity of the instrument, thus responses were obtained. A correlation between peoples patronage in internet banking (dependent variable), and their respective internet accessibility (independent variable) and their perception about internet banking (independent variable). Two hypothesis was set; a null hypothesis and an alternate hypothesis was set and the results discussed.

\subsection{Sampling and Questionnaire Development.}

A survey method was used to carry out the study. The target population for the study comprised all individual customers and workers of all the banking companies that operate in Ghana commercially and mandated to do so by the bank of Ghana. There is no available statistics on the total number of individual customers in the banking industry in Ghana however a total of a hundred and sixty-two banks (162) operate in Ghana among which 135 are rural banks and 27 are commercial banks (Bank of Ghana 2015). In all 300 questionnaires were administered to the Ghanaian public a total of 249 response came back. Sampling technique was used as result of limited data on the total population of customers of banks in Ghana and cost and time constraints, a convenient sample size of proportion of two hundred and fifty three customers were drawn from the known (27) commercial banks that operate in Ghana with purpose of drawing at least customers from each of the Banking companies operating in Ghana that offer services mandated and approved by the apex bank; Bank of Ghana.

3.2.1 Research Questions.

The questionnaire was developed in such a way that respondents could answer them with the minimum difficulty. Respondents were in general supposed to indicate which bank services were provided by their banks and how often such services had revolutionized their bank patronage.

I. How many years have you had a Bank Account?

II. How often do you use your bank online service?

III. How often do you use your internet services?

IV. Why have you never use an online Service?

V. Would you trust a Bank that only operates Online?

VI. Which of the following Services are provided by your Bank

VII. How satisfied are you working through E-channels?

3.2.2 Hypothesis

Data collected was analyzed using Correlation Statistics that were adopted in Statistical Package for Social Science (SPSS). The Spearman and Kendall's tau-b correlation test was adopted. The common person correlation was not applicable in our analysis since our variables were mostly nominal and ordinary instead of scale.

In trying to find out how internet accessibility influenced peoples patronage in internet banking, our respondents were supposed to choose from a scale of 1-4 : 1-daily, 2-weekly, 3-monthly, and 4-when needed; We then set up our two hypothesis;

1. H0- the Null Hypothesis assumes that, there is no effect of internet accessibility on peoples patronage in internet banking, thus our correlation coefficient is $=0$. 
2. H1 - The Alternate Hypothesis however states that, there is either a negative or a positive correlation between peoples access to internet and their patronage in internet banking, thus, the correlation coefficient is not $=0$.

\section{Results and Analysis}

4.1 Demographics of Respondents.

\subsubsection{Gender and Age of Correspondents}

Table1 below shows the demography of the respondents. Out of the total 249 respondents 156 were males representing 62.7 percent of the total respondents and 90 were females representing 36.1 percent the remaining 3 , which was 1.2 percent, didn't want to specify their sex. There is clear major gap between the sexes, which shows that a lot of women may not have access to internet or were not willing to answer these questionnaire compared to the men although the women by a small margin were willing and more open to be approached than the men to help with the research. This is an indication that there is a major difference between men and women when it comes to the patronage innovation technology in the banking industry.

\begin{tabular}{|l|l|l|}
\hline Category & Frequency & Percentage (\%) \\
\hline Gender & & \\
Male & 90 & 36.1 \\
Female & 156 & 62.7 \\
Silent & 3 & 1.2 \\
Total & $\mathbf{2 4 9}$ & $\mathbf{1 0 0}$ \\
Age & & \\
$18-25$ & 55 & 22.1 \\
$25-30$ & 151 & 60.6 \\
$30-40$ & 36 & 14.5 \\
above 40 & 7 & 2.8 \\
Total & $\mathbf{2 4 9}$ & $\mathbf{1 0 0}$ \\
& & \\
Education & 186 & 77.8 \\
Bachelor degree & 43 & 18 \\
Master Degree & 9 & 3.8 \\
Ph.D & 1 & 0.4 \\
Post Doctorate. & $\mathbf{2 3 9}$ & $\mathbf{1 0 0}$ \\
Total & & \\
\hline
\end{tabular}

Table.1: Demography of respondents

Source; field work 2018

The highest respondent age was between 25-30yrs, which segregate as active innovation technology users; which 60.6 percent between 18 -25yrs represented 22.1 percent and 30-40yrs represented 14.5 and the above 40 represented 2.8 percent. This perfectly skewed distribution was very symbolic of the research setting. Proportionally the number of respondents between the ages of 18-25yrs and 25-30yrs representing the active youth outstripped the other categories to mean dominant use of the banks. Those below 20yrs clearly showed that in the Ghanaian setting individuals who had banking access or accounts in this category where from the minority affluent and hence the majority seen as young or didn't have the financial strength to hold one (bank account) had no business with the banks.

4.2.3 Educational Level and Banking Experience of Respondents.

Out of the 239 respondent $77.8 \%$ were bachelor degree holders, $18 \%$ were Master's degree holders, $3.8 \%$ were PHD holders and $0.4 \%$ was a Post Doctorate holder, this analysis shows that most pf the respondent had higher level of education which suggest the selected population are well abreast with the concerning issue of innovation technology. Out of the 248 respondent $52 \%$ have had their account from 5-10 years.21.8\% have had their account for more than 10 years, 14.9 have had their account for 3-5 years, $10.9 \%$ have had their account for 1-3 years $0,4 \%$ have had their account from 33-40 years now.

4.2.4 Rate of Patronizing Bank Online Services

Subjectively, the number of times customers transact business with their banks gives a hint about the level of satisfaction and loyalty to the bank. Due to this, respondents were asked to indicate how often they use their banks online services. The results Indicate that customers did use the banks averagely between daily, weekly and monthly, majority uses it when needed, this paper can't tell whether it is dissatisfaction making it worth researching in another study.

It can be seen from Figure 3 below that most customers showed various ways of using the banks however Automated Teller Machines (ATM) was the main means through which customers in Ghana transact business 
with the banks. The respondents indicated that telephone was very expensive. Visiting the Bank and online Banking has the lowest percentage, which could be due computer illiteracy, and Internet was difficult to come by. In fact, Internet is an 'urban commodity' in Ghana and only a few affluent ones can afford.

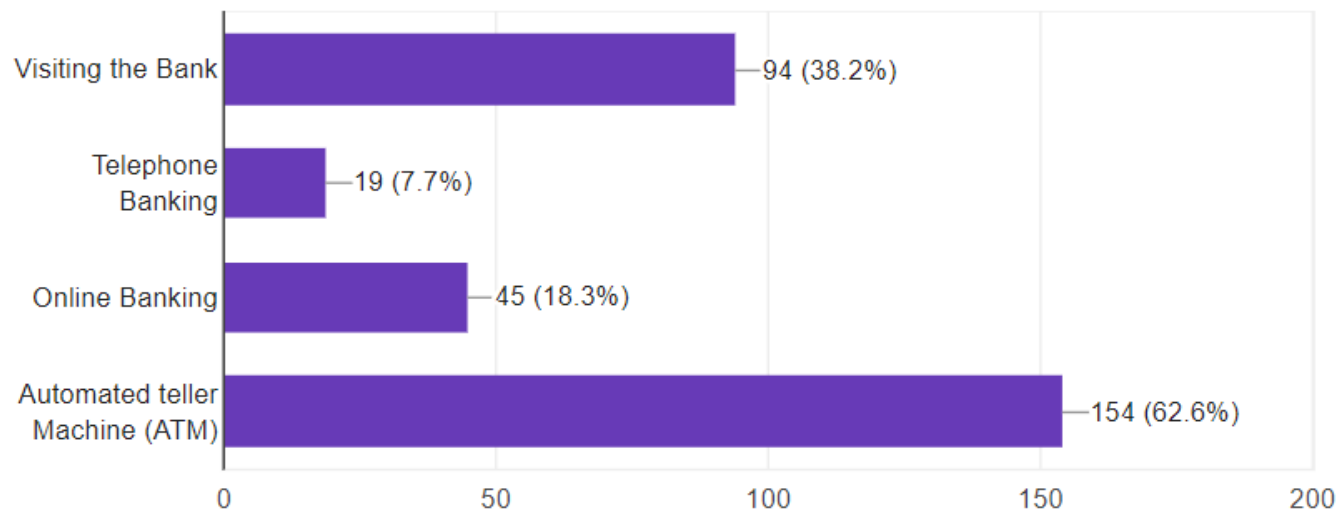

Figure 3 Means of patronizing the Bank.

Source:Field work 2018.

Telephone Banking, Credit cards, Debit cards, Mobile banking, Internet Banking Electronic Banking, Automated Teller Machines (ATM) are all due to innovation technology banks are able to provide these services to their consumers, Out of the 250 respondents $85.2 \%$ of the Banks provide ATM to their consumers, $70 \%$ provide their consumers with Mobile Banking, $62 \%$ provide Internet banking to their consumers, $47.2 \%$ provide Debit cards to their consumers, $45.2 \%$ provide electronic Banking ,37.6\% provide credit cards and $30.4 \%$ provide Telephone Banking.

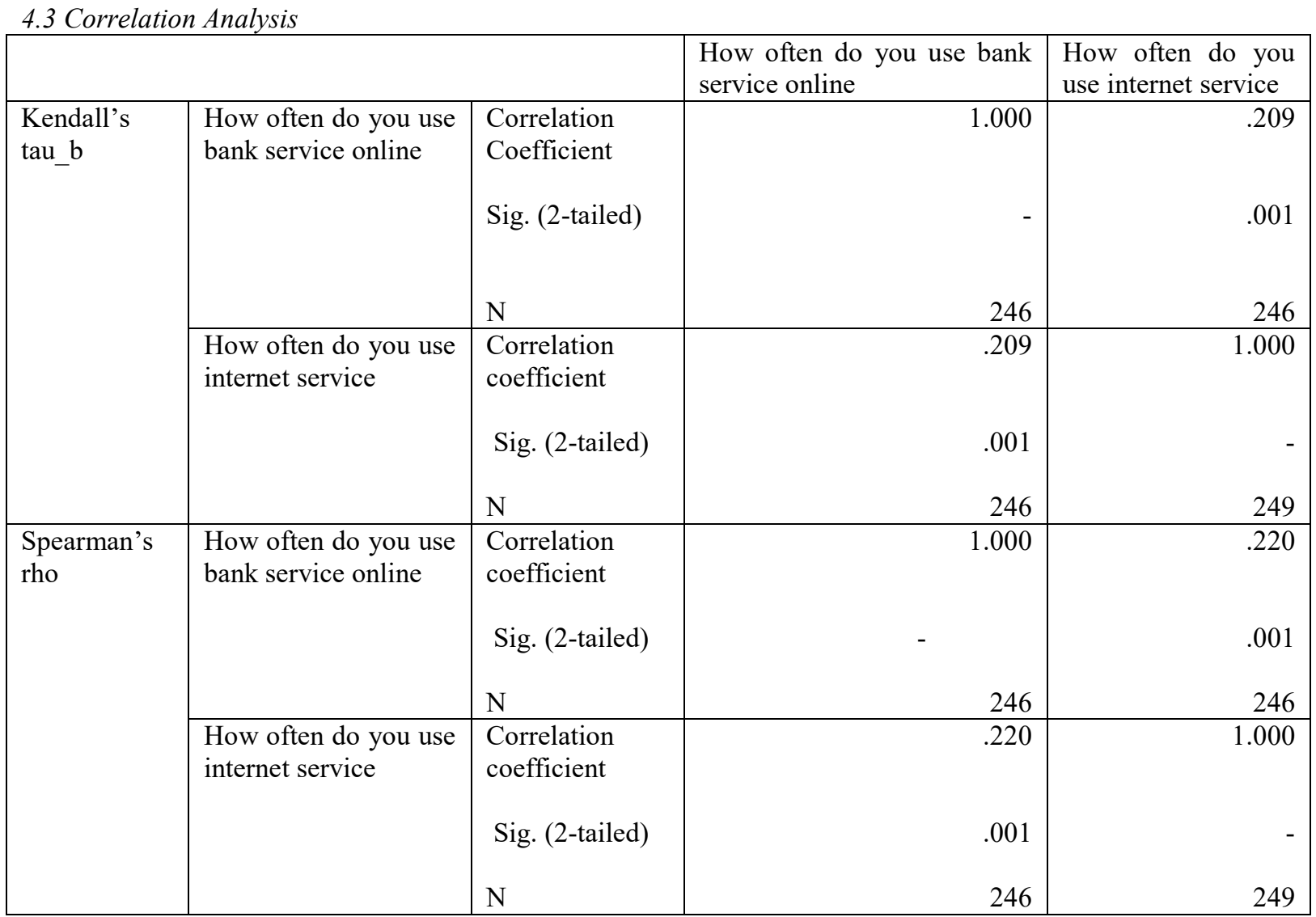

Correlation is significant at the 0.01 level (2-tailed)

Table. 2 Correlation of Internet Accessibility and Patronage in Internet Banking.

Table 2 above shows the Kendall's tau-b and the spearman's correlation results of internet Accessibility and 
patronage of internet banking. Out of 254 respondents, their respective responses from a scale of $1-4$ (from frequent - seldom or circumstantial access) of Internet accessibility and Internet banking; the results show that there is a significant positive relationship between availability of Internet and their patronage of internet banking. The Kendall's and the spearman's correlation model all show a positive relationship; however, the Spearman's model has a high coefficient value than the Kendall'. The P-value of 0.001 for both Kendall's tau-b and Spearman test show that the Null hypothesis can be confidently rejected with the $95 \%$ confidence level.

\begin{tabular}{|c|c|c|c|c|}
\hline & & & $\begin{array}{l}\text { How often do you use bank } \\
\text { service online }\end{array}$ & $\begin{array}{l}\text { How often do you } \\
\text { use internet service }\end{array}$ \\
\hline \multirow[t]{2}{*}{$\begin{array}{l}\text { Kendall's } \\
\text { tau_b }\end{array}$} & $\begin{array}{l}\text { How often do you use } \\
\text { bank service online }\end{array}$ & $\begin{array}{l}\begin{array}{l}\text { Correlation } \\
\text { coefficient }\end{array} \\
\text { Sig. (2-tailed) } \\
\text { N }\end{array}$ & $\begin{array}{r}1.000 \\
- \\
246 \\
\end{array}$ & $\begin{array}{r}-.135 \\
.017 \\
244\end{array}$ \\
\hline & $\begin{array}{l}\text { How often do you use } \\
\text { internet service }\end{array}$ & $\begin{array}{l}\begin{array}{l}\text { Correlation } \\
\text { coefficient }\end{array} \\
\text { Sig. (2-tailed) } \\
\mathrm{N} \\
\end{array}$ & $\begin{array}{r}-.135 \\
.017 \\
244 \\
\end{array}$ & $\begin{array}{r}1.000 \\
- \\
246 \\
\end{array}$ \\
\hline \multirow[t]{2}{*}{$\begin{array}{l}\text { Spearman's } \\
\text { rho }\end{array}$} & $\begin{array}{l}\text { How often do you use } \\
\text { bank service online }\end{array}$ & $\begin{array}{l}\text { Correlation } \\
\text { coefficient } \\
\text { Sig. (2-tailed) } \\
\text { N }\end{array}$ & $\begin{array}{r}1.000 \\
246\end{array}$ & $\begin{array}{r}-.156 \\
.015 \\
244\end{array}$ \\
\hline & $\begin{array}{l}\text { How often do you use } \\
\text { internet service }\end{array}$ & $\begin{array}{l}\text { Correlation } \\
\text { coefficient } \\
\text { Sig. (2-tailed) } \\
\text { N }\end{array}$ & $\begin{array}{r}-.156 \\
.015 \\
244 \\
\end{array}$ & $\begin{array}{r}1.000 \\
- \\
246 \\
\end{array}$ \\
\hline
\end{tabular}

Correlation is significant at the 0.05 level (2-tailed)

Table3. Correlation of Internet banking Accessibility and Preference for ATM, Mobile Banking \& Visiting the Bank.

Table 3 above also uses the same Kendall's tau-b, and Spearman model to analyze the correlation between internet banking users and their preference for either visiting the bank, using mobile banking or ATM for bank transactions. In the order of the scale factor, 1-3, where 1- visiting the bank, 2-mobile banking, and 3-ATM, a positive correlation in any of Spearman's or Kendall's tau-b model would signify that, in as much as our respondents patronize internet banking, they would still opt for visiting the bank given the three options stated above. However, the opposite is the case in our study.

The correlation coefficient of $-0.135^{*}$ in the Kendall's model and that of $-0.156^{*}$ in the spearman's model signifies a negative correlation at a $95 \%$ confidence interval. This implies that, the more people have access to internet banking, the more they would prefer ATM services than visiting the bank or mobile banking. Moreover since both correlation results have a p-value of less than $1 \%$, we can confidently reject the null hypothesis and accept the alternate hypothesis.

\subsection{Implications of Correlation Results}

In testing for the influence of internet accessibility on our respondent's patronage in internet banking, we realize a significant positive correlation between the two variables. This implies that, as long as technology continues to surge and innovations and discoveries are making internet more accessible, banking institutions should make significant efforts to expand their internet banking systems, making it user friendly and easily accessible, since people would prefer internet banking to visiting the banks. Internet has become an integral and basic part of livelihood and so is Money. Therefore an increase in recent global technology and innovation should propel bankers to utilize this opportunity to attract these potential banking customers (internet users).

There is also a greater concern for bankers and managers to emphasize on increasing both their on-site and off-site ATM services with the advancement of recent global technology and innovations. People's access to technology has influence their choice for internet banking probably due to the feasibility and it's time saving characteristics. It has also influenced people preference for ATMs and mobile banking services instead of 
visiting the banks. The amount involved in constructing a bank and employing bank tellers (service personnel) could be used in establishing ATMs at vantage points to increase customers' satisfaction.

\section{Conclusion and Recommendations}

The overall study of the research is to identify the influence innovation technology has brought on the banking industry. Emerged from the study were: the ease use of innovation technology products by customers and employees of the bank. The respondents from the survey shows positive significance impact of innovation technology in their daily use of bank services, due to this, the banking industry keeps expanding and introducing new varieties of innovation to be able to gain stands in competition with other banks and financial institutions. Based on the analysis of responses from the questionnaires, though a few would still prefer to trek to the banks to enjoy person-to-person services; many would however prefer mobile banking and automated banking (independent customer services). It is therefore not surprising that the surge in the annual Ghanaian mobile data subscription; 18.8million in 2016 to 22.9 million subscribers in December 2017 and a data penetration rate of about $80 \%$ (NCA, 2017 annual report), which serves as a best proxy for accessibility to internet and mobile banking, coupled with the steady in increase in the accessibility to Automated Teller Machines (ATM) which could equally represent as a proxy for technology and innovation in the Ghanaian banking industry; 3.8 ATMs/100000 adults in 2008 to 10.1 ATMs in 2015 and sudden drop in 2016 to 5.2 ATMs(probably due to the surge in the population growth of Ghana in between 2015 and 2017) (data.Worldbank,2017), have both resulted in a corresponding steady rise in bank deposits per 1000 adults in Ghana (a probable proxy for bank patronage by Ghanaians). Data from the World Bank indicates that, 210 Ghanaians per each 1000 adults preferred to save with banks in 2005. This number increased to 284 in 2008; 478 in 2012; 680 in 2015 and a corresponding (to ATMs) drop to 640 in 2016. In view of the demography of the actual Ghanaian Population where our sample was taking from, our correspondents perfect validate our chosen scope and sample. Ghana is among the youthful-population countries in SSA, with about 38\% of its population below 15 years and about $52 \%$ between the ages of 15-54 years. People between these ages are more fascinated about internet and technology: more centered on utilizing their energy for money-hunting than to waiting in long queues at banks and service centers as clearly indicated in our study. As Ghana seeks to become the hub and gateway to West-African trade and investments, the financial sector and thus the banking sector need to welcome and consequently introduce a more feasible and access to banking services, such as withdrawals, bank deposits, inter and intra bank transfers, feasibility in swift account wirings and regulations, This would only satisfy the Ghanaian customers, but would attract foreign investors and tourists and other expatriates; increase the index for the rate of doing business in Ghana and congruently boost the Ghanaian economy through substantial GDP contribution. The study just focused most importantly on the positive aspects of development that innovation technology has brought into the banking industries. Future study can be focused on both positive and negative implication of innovation technology on the banking industries. Other study can also be focused on comparing well-advanced banks to rural banks to differentiate short come with regards to innovation technology.

\section{References.}

Akinuli, O.M. (1999), "Information Technology in Ghana's Banking Industry: Operational Applications, Problems and Future Challenges", CBN Bullion, 23(3), 71-75.

Alu, A. O. (2000). Effects of Information Technology on Customer Services in the Banking Industry in Nigeria.

Baker, K. A. (2002). Organizational communication in Management Benchmark Study/U.S. Office of

Science/Department of Energy.

Bayrakdaroglu, A., Ersoy, E., \& Citak, L. (2012). Is There a Relationship Between Corporate Governance and Value-based Financial Performance Measures? A Study of Turkey as an Emerging Market. Asia-Pacific Journal of Financial Studies, 41(2), 224-239. doi:10.1111/j.2041-6156.2012.01071.x

Fisher, A. G. (1998). Uniting practice and theory in an occupational framework: 1998 Eleanor Clarke SlagleLecture. American Journal of Occupational Therapy, 52, 509-521

Gardner, B. (2009). Modelling motivation and habit in stable travel mode contexts. Transportation Research Part F: Traffic Psychology and Behaviour, 12(1), 68-76.

Gutek, B.A. \& Welsh, T. (2000). The brave new service strategy. New York, NY: AMACOM, a division of American Management Association. [Selected one of the 30 best business books of the year 2000 by Soundview, publishers of Business Executive Summaries.]

Ilo Joseph. Ani Wilson. Chioke. Impact of Technological innovation on delivery of banking in Nigeria. International Conference on Economics, Education and Humanities (ICEEH'14) Dec. 10-11, 2014 Bali (Indonesia)

Joseph E. Stiglitz, 2010. "Risk and Global Economic Architecture: Why Full Financial Integration May Be Undesirable," NBER Working Papers 15718, National Bureau of Economic Research, Inc.

Josiah Aduba, Nancy Kingoo, The Relationship between Electronic Banking and Financial Performance among 
Commercial Banks in Kenya Journal of Finance and Investment Analysis, vol.1, no.3, 2012, 99-118 ISSN: 2241-0988 (print version), 2241-0996 (online) Scienpress Ltd, 2012

Kotler, P., John, B. \& Makens, J.C., (2003), Marketing for Hospitality and Tourism. The third edition, New Jersey, Pearson Prentice Hall.

Laukkanen, T., S.Sinkkonen,M. Kivijarvi,and P.Laukkanen, "Innovation resistance among mature consumers,"International Journal of Marketing, Vol. 24, No. 7: 419-427, 2007

Lean, O.K., Zailani, S., Ramayah, T. and Fernando, Y. (2009) Factors influencing intention to use-government services among citizens in Malaysia. International Journal of Information Management, 29(6), 458-475.

London.Tan, Y. H., \& Thoen, W. (2001). Toward a generic model of trust for electronic com-merce. International Journal of Electronic Markets,5(2), 61-74.

Muhammad Nadeem, Rashid Ahmad, Naveed Ahmad, Syeda Rabia Batool,Ammar Ahmed, Muhammad Nouman Shafique, SINGAPOREAN Journal Of business economics, andmanagement studies Vol.3, no.12, 2015

Niels Peter Mols, (1998) "The behavioral consequences of PC banking", International Journal of Bank Marketing, Vol. 16 Issue: 5, pp.195-201, https://doi.org/10.1108/02652329810228190

Pala, E., Kartal, B. 2010, "Banka Müşterilerinin İnternet Bankacılı̆̆ı ile İlgili Tutumlarına Yönelik Bir Pilot Araştırma”, Yönetim ve Ekonomi, Vol.:17, No. 2, pp. 43-61

Pavitt, K. (1984). "Sectoral patterns of technical change: towards a taxonomy and a theory". Research Policy. 13 (6): 343-373. doi:10.1016/0048-7333(84)90018-0.

Peter Tufano, Handbook of the Economics of Finance Chapter 6 - Financial Innovation

Volume 1, Part A, 2003, Pages 307-335

Roger, E. M., (1995), Diffusion of Innovations, Fourth edition, New York: Free Press.

Roman Beck, Sven Weber, Robert W. Gregory (2012). Theory-Generating Design Science Research. Inf Syst Front, pp. 1-15

Sanders, M. (2000). Global E-commerce Approaches Hypergrowth, Cambridge, MA: Forrester Research, Inc.

Scott Frame \& Larry D. Wall \& Lawrence J. White, 2012. "The devil's in the tail: residential mortgage finance and the U.S. Treasury," FRB Atlanta Working Paper 2012-12, Federal Reserve Bank of Atlanta.

Tan, M. and Teo, T.S.H. (2000). 'Factors influencing the adoption of Internet banking',Journal of the Association for Information Systems, vol. 1, pp. 1-44.

Teo, T. S. H., \& Pok, S. H. (2003). Adoption of WAP-enabled mobile phones amongInternet users.Omega: The International Journal of Management Science,31(6),483-498.

Villates, Dominique. 1997. «Demain, la banque à distance». Banque, no. 585, p.68-70.

W. Scott Frame \& Lawrence J. White, 2004. "Emerging competition and risk-taking incentives at Fannie Mae and Freddie Mac," FRB Atlanta Working Paper 2004-4, Federal Reserve Bank of Atlanta

Yasuharu, U. (2003). Economic analysis of information system investment in Japanese Banks. Taga Shuppan, Japan.

Yıldı, S., Karadirek, G. 2014, "Elektronik Hizmet Kalitesi Algılamaları: Bireysel İnternet Bankacılığı Kullanıcıları ÜzerineBir Uygulama”, Gümüşhane Üniversitesi Sosyal Bilimler Elektronik Dergisi, No. 10, pp. 303-329 
Descriptive Statistics

Descriptive Statistics

\begin{tabular}{|c|c|c|c|c|c|c|c|c|c|}
\hline & \multirow{2}{*}{\begin{tabular}{|c|}
$\mathrm{N}$ \\
Statistic
\end{tabular}} & \multirow{2}{*}{\begin{tabular}{|l} 
Minimum \\
Statistic
\end{tabular}} & \multirow{2}{*}{$\begin{array}{l}\text { Maximum } \\
\text { Statistic }\end{array}$} & \multicolumn{2}{|c|}{ Mean } & \multirow{2}{*}{$\begin{array}{c}\text { Std. } \\
\text { Deviation } \\
\text { Statistic }\end{array}$} & \multirow{2}{*}{$\begin{array}{l}\text { Variance } \\
\text { Statistic }\end{array}$} & \multicolumn{2}{|c|}{ Skewness } \\
\hline & & & & Statistic & $\begin{array}{l}\text { Std. } \\
\text { Error }\end{array}$ & & & Statistic & $\begin{array}{l}\text { Std. } \\
\text { Error }\end{array}$ \\
\hline Male or & 246 & 0 & 1 & .63 & .031 & .483 & .233 & -.560 & .155 \\
\hline Age of re & 249 & & 4 & 1.98 & .044 & .695 & .483 & .540 & .154 \\
\hline What is your highest level of education & 239 & 1 & 33 & 1.39 & .137 & 2.121 & 4.500 & 14.036 & .157 \\
\hline $\begin{array}{l}\text { how many years have you had a bank } \\
\text { account }\end{array}$ & 248 & 1 & 4 & 2.84 & .056 & .888 & .789 & -.630 & .155 \\
\hline $\begin{array}{l}\text { how often do you use bank service } \\
\text { online }\end{array}$ & 246 & 1 & 4 & 3.51 & .060 & .933 & .871 & -1.754 & .155 \\
\hline How often do you use internet service & 249 & 1 & 4 & 1.66 & .077 & 1.218 & 1.483 & 1.359 & .154 \\
\hline which of the following do you use often & 246 & 1 & 6 & 2.91 & .089 & 1.396 & 1.948 & .290 & .155 \\
\hline $\begin{array}{l}\text { why have you never use an online } \\
\text { banking service }\end{array}$ & 200 & 1 & 4 & 2.80 & .061 & .868 & .754 & -.531 & .172 \\
\hline $\begin{array}{l}\text { would you trust a Bank thats only } \\
\text { operates online }\end{array}$ & 248 & 0 & 2 & .74 & .048 & .762 & .581 & .473 & .155 \\
\hline $\begin{array}{l}\text { what online Banking service do you the } \\
\text { most }\end{array}$ & 227 & 1 & 6 & 2.96 & .100 & 1.503 & 2.259 & .092 & .162 \\
\hline $\begin{array}{l}\text { which of the following services are } \\
\text { provided by your bank }\end{array}$ & 250 & 1 & 77 & 7.71 & .291 & 4.606 & 21.212 & 13.703 & .154 \\
\hline $\begin{array}{l}\text { In general what do you feel about E- } \\
\text { banking, as a new system of delivering } \\
\text { Banking Services }\end{array}$ & 246 & 1 & 4 & $2 \mathrm{a} .59$ & .057 & .888 & .789 & .507 & .155 \\
\hline $\begin{array}{l}\text { Indicate the service offered through } \\
\text { ATM in your Bank in your Bank }\end{array}$ & 248 & 1 & 7 & 4.75 & .139 & 2.194 & 4.814 & -1.101 & .155 \\
\hline $\begin{array}{l}\text { How satisfied are you working through } \\
\text { E-channels }\end{array}$ & 244 & 1 & 4 & 2.30 & .048 & .746 & .556 & -.128 & .156 \\
\hline The technology I work with helps & 228 & 1 & 5 & 2.72 & .098 & 1.475 & 2.174 & .453 & .161 \\
\hline $\begin{array}{l}\text { The downsizing of employees is due to } \\
\text { emerging technology but efficiency in } \\
\text { terms of productivity has increased } \\
\text { would you recommend any form of }\end{array}$ & 243 & 1 & 4 & 2.11 & .051 & .801 & 641 & .340 & .156 \\
\hline $\begin{array}{l}\text { internet banking to your friends and } \\
\text { colleagues } \\
\text { computerised transaction has helped me }\end{array}$ & 247 & 1 & 5 & 1.87 & .061 & .958 & .918 & .877 & .155 \\
\hline $\begin{array}{l}\text { to reduce the waiting time for any } \\
\text { transaction in the bank }\end{array}$ & 246 & 1 & 5 & 1.63 & .047 & .744 & .553 & 1.749 & .155 \\
\hline $\begin{array}{l}\text { what do you think is the reason behind } \\
\text { the introduction of internet banking. }\end{array}$ & 241 & 1 & 4 & 2.32 & .080 & 1.236 & 1.527 & .093 & 157 \\
\hline $\begin{array}{l}\text { How do you think Employees benefit } \\
\text { from Electronic Banking? }\end{array}$ & & 1 & 5 & 2.63 & .080 & 1.240 & 1.537 & 1.119 & .156 \\
\hline Valid N (listwise & 16 & & & & & & & & \\
\hline
\end{tabular}

